\title{
山地渓流における流路形態と土砂流出
}

\section{Channel pattern and sediment transport in a steep gravel bed river}

$\begin{array}{lll}\text { 京都大学防災研究所 } & \text { 沢 田 豊 明 Toyoaki SAIADA } \\ \text { 京都大学防災研究所 } & \text { 声 田 和 男 Kazuo ASHIDA }\end{array}$

This study describes the sediment transportation and its relating phenomena typical in mountain streams. In a stream with the step-pool system, the sediment transportation depends greatly on sediment storage in the pools. The destruction of armor coat results in the destroy of step-pool system, which causes a change of stream morphology. In addition, a meandering channel, the characteristics of which accords with the degree of the flood, is formed.

Stream channels do not change so much in the conditions the armor coat can not be destructed even if a flood comes. In such cases, the sediment transportation depend greatly on the sediment storage in the step-pool system. In the case that the destruction of armor coat occurs, stream channels change very much.

Debris flow brings a great change to the stream channel in the areas of its running-out; deep erosion in the occurrence areas and rapid aggradation in the ceasing area. In the deposition area, a new stream channel is formed due to the eroding action of water flow after the event. Keymords: sediment transport, channel pattern, step-pool, gravel bed

\section{1.まえがき}

河川流域における環境の変化を予測するためには、 土砂の移動を予測することが重要な課題となっている 。現在、土砂磷の移動を予測するために、その移動機 錸を含めて種々の流砂量式が提案されている。しかし 、それらの式を現地の河川へ適用しようとする場合、 上流から供給される土砂の量や粒径分布などの予测と 共に、土砂磁の輸送の場であり、かつ供給の場である 流路の特性を的確に把握することが必要である。特に 、山地河川においては勾配が急で、河道構成材料の粒 度分布む広い。そのため、種々の流砂形態が発生する ばかりでなく、流砂の量的・質的変動む大きい。

本研究は流砂現象の予測を目的として、流路形態と 流砂現象の関係を明らかにしようとするすのである。 流砂は掃流砂と土石流、流路形態は平面形状、河幅、 河床縦断・横断形状、河床勾配、河床材料などを対象 としている。

\section{2. 䝷湘流城の概要 ${ }^{11}$}

観測流域の足洗谷は、岐阜県の北東部の神通川水系 蒲田川の支流で、流域面積 $7.2 \mathrm{~km}^{2}$ で、焼岳の西側に源 を発している。流域の概略は図 1 に示すとおりで、流 砂観測は図中の A，BおよびC地点で行われている。

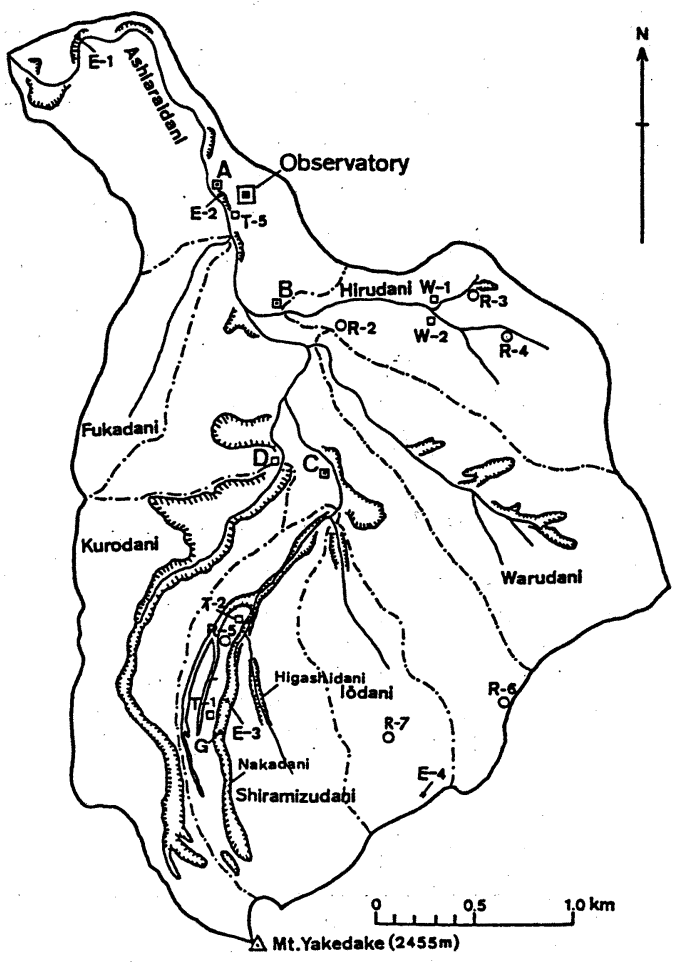

図 1 足洗谷の概要

$\mathrm{A}$ ：深谷流砂観測点、 $\mathrm{B}$ ：ヒル谷観測点 $\mathrm{C}:$ 白水谷観测点、 
流路形態は足洗谷本川のA地点付近、ヒル谷本川、白 水谷上流の E-3付近で調查されている。足洗谷の河床 縦断形状は図2に示すとおりで、上記の調查区間の平 均勾配は、 $4^{*}, 12^{\circ} お よ ひ ゙ 20^{\circ}$ である。したがって、 これらの調査区間は土石流の発生域から流下域まで含 まれる。河床材料の粒径分布は図 $3 に$ 示すように広い 範囲を示しているが、焼岳火山の噴出物の特性に支配 されている。この流域における土砂生産の大半は、こ の堆積物の侵食によるむのであり、土石流の発生源に なっている。

\section{3. 階段状流路と流础 ${ }^{21}$}

アーマーコートの破壊がない溪流では巨碟が嚙み合 ってプールとステップからなる階段状の河道が形成さ れることが多い。この様な流路において、流砂はプー ルの容積と掃流力によって調節されるため、流量と流 砂量が一対一に対応しないことが多い。ヒル谷流域に は図3に示すような粒径分布を有する砂磷と最大粒径 が50から $100 \mathrm{~cm}$ の巨啋からなる階段状の流路が形成さ れている。

この様な流路において図3のHbに示すような粒径分 布を示す土砂が輸送されている。図4 はヒル谷本川の 平均勾配 $12 *$ の河床と河床の比高差の流路に治った分 布を示したすのである。この図に現れている小さな変 動はステップ・プールに相当するもので、このプール

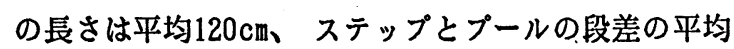
は65cm、ステップの平均長さは約 $200 \mathrm{~cm}$ である。これ より大きな縦断変動の周期が約40范であること,この流 路の河幅が約4mであることに注目すれば、これらの值 は,河幅 $\mathrm{B}$ と蛇行波長 $\mathrm{L}$ と関係 $\mathrm{L}=10 \mathrm{~B}$ で説明され る蛇行波長40mに相当するすのと考える。

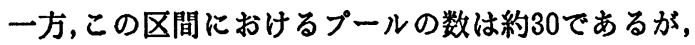
約700mの区間における約190 のプールの容積の分布は 図5に示すとおりである。この区間におけるプールの 平均容積は $0.189 \mathrm{~m}^{3}$ であり、これはステップの落差に 支配されているようである。この様なプールに貯留さ れる土砂量と年間流出土砂量の長期の経年的傾向を見 るために、それらの累積状態を図6に示す。この図か ら明らかなように年単位で長期の流出土砂量をみると 全流砂量の一割程度がプールによって調䬣されている 傾向が認められる。このプールの容積は $700 \mathrm{~m}$ 区間で 35 $\mathrm{m}^{3}$ となっている。しかし、実際に調查された最大貯留

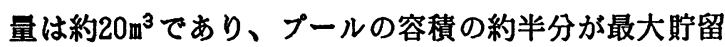

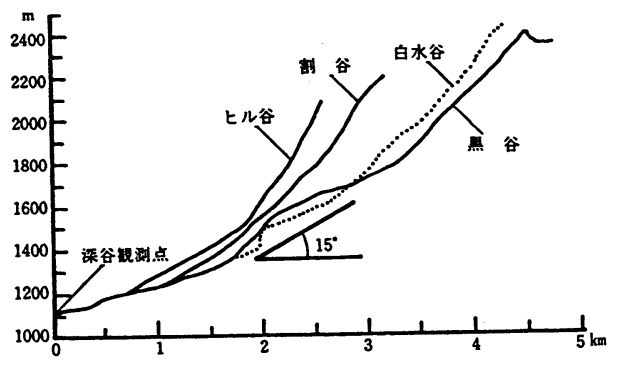

図 2 足洗谷流域支川の河床勾配 （深谷観测点：本川）

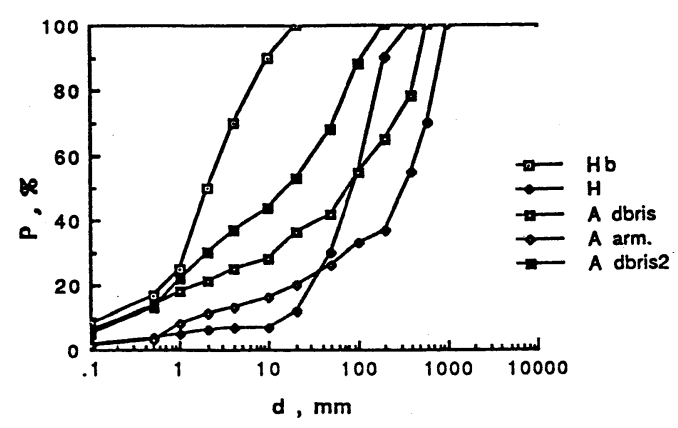

図 3 足洗谷流域の河床材料の粒径分布

$\mathrm{Hb}$ : ヒル谷出口の流砂

H : ヒル谷本川河床

Adbris：土石流堆積物

Aarm.：足洗谷本川河床アーマーコート
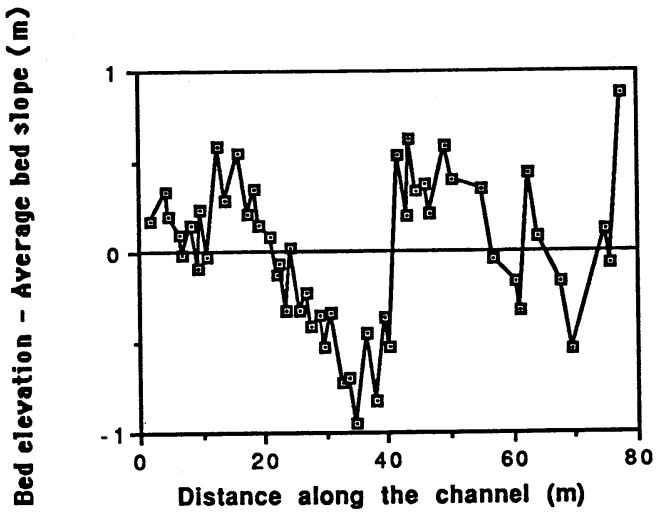

図 4 ヒル谷本川の河床高から平均河床高を 差し引いた值の流路に沿う分布 
容量となっている。

一方、出水毎に流量と流砂量の関係をみると、図 7 に示すように出水毎に異なっている。また、一出水に おいてす、その関係は変化している。この様な現象は プールの町留量Vbと流砂観測点より上流における眝留 量Vbの分布に支配される。その貯留量Vbをパラメータ とすれば、洪水期間および洪水毎に変化する流量と流 砂量の関係が、この貯留量Vbの変化で説明される。

以上のような安定したステップ・プールが形成され ている流路では、上流から供給される掃流砂の輸送に おいてプールの容積・配置と流砂量の相対的な関係が 重要な役割を演じているものと考える。以上のような 点から、予測対象となる流砂現象の時間的・空間的ス ケールに応して流路特性のスケールを考虑することが 必要である。

\section{4. 流路変動と流础 ${ }^{31}$}

上流で多量の土砂生産が行われている溪流では、流 路の変動が大きく流砂形態む複雑である。この様な流 路の形態について足洗谷本川の流砂観測点付近におけ る縦断および平面形状を見ると図8および9の様にな っている。図8は平均河床勾配 4" の河床と河床の高 低差の流路に沿った分布を示したものである。この図 に現われている微小な変化はステップ・プールを示す むので、それより規模の大きな変化は波長が $200 \mathrm{~m}$ 程度 で図9に示す規模の大きな蛇行波長に相当している。 その他、この図には波長が50m 程度の中規模の変化も 認められ、ここでは規模の異なる二つの流路縦断形状 が複合されている。この規模の大きな変化の周期は洪 水時の平均流路幅の $20 \mathrm{~m}$, 一方、中規模のむのは平水時 の平均水面幅の 5 mの約10倍となっており、ここでも蛇 行波長が河幅の10倍になる関係との類似性が認められ る。これらの事実は、この様な規模の流路縦断形状が 流路の蛇行に関連していることを示している。

次に、流路の平面形状をみると、図のに示す曲線は 小規模な蛇行の振幅の中心を結んだすので、この曲線 は図中の直線によって波長が $200 \mathrm{~m}$ 程度の蛇行を示すこ とが明鄚に表わされている。以上のように、中規模な 蛇行は約 $50 \mathrm{~m}$, 大規模なむのは約 $200 \mathrm{~m}$ の蛇行波長を示す が,上記の河幅との関係が成り立っている。ところで、 年に一回程度の洪水では、因 9 の規模の大きな蛇行の 変動は認められず、この様な規模のものは土石流の発 生によって生じている。一方規模の小さなむのは、年

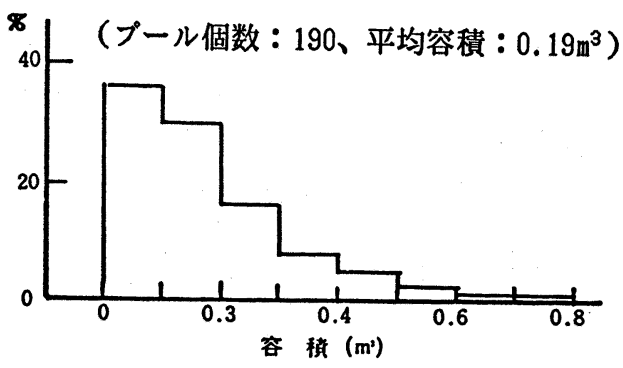

図 5 ヒル谷本川のプールの容積の度数分布

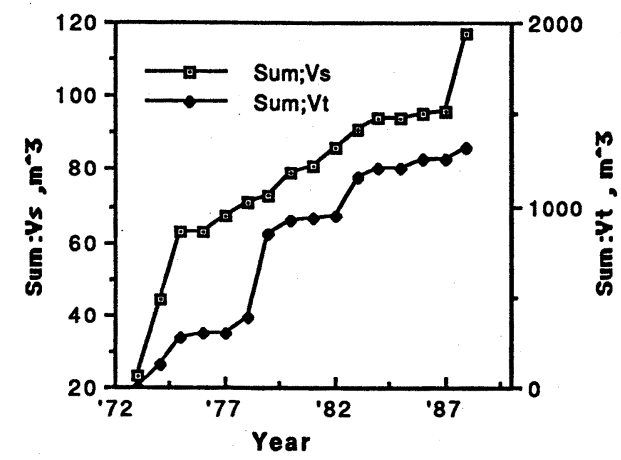

図6ヒル谷出口における累積流砂量Vtと

本川河道プールの累積貯留土砂量Vs

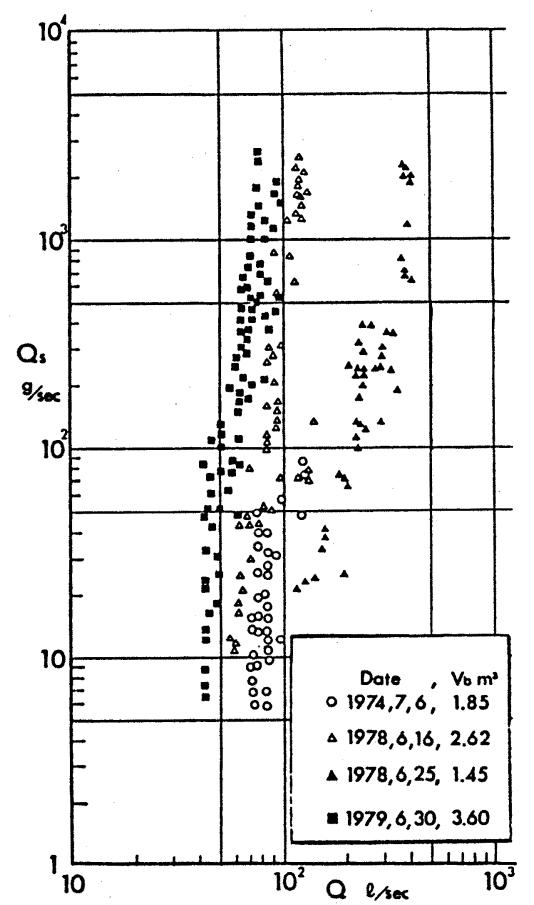

図 7ヒル谷本川河道プールの総貯留量Vb をパラメーターとする木川出口の 流量Q と流砂量Qsの関係 
に数回の洪水です変怔しており、この様な変動を伴う 流路における土砂流出は图10に示すような領域に分け て考える必要がある。

この図において(1) はアーマーコートの破壊や溪岸 侵食がない状態で、士砂の移動が発生する。（2）はア ーマーコートの破壊に伴い土砂の移動が発生する。

（3）は渓岸の侵食によって生産された土砂が移動する。 （4）は流路の移動によって新しい河床の土砂が移動する。 以上の領域を考虑して流砂量を予想する場合、

(1)の 領域では上流からの土砂の量および粒径と水理量が与 えられれば流砂量が求められる。しかし、(2)，(3)お よび(4)の領域の場合、アーマーコートの破壊、溪岸 侵食および流路の変動を予測し、それらに伴う河床材 料の粒径の変化を考慮する必要がある。

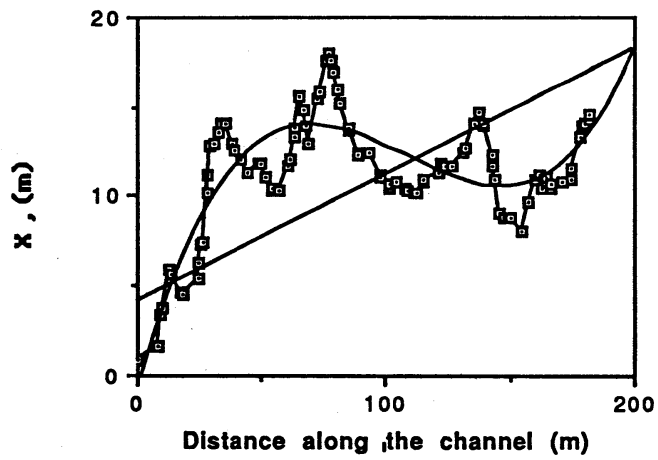

図9足洗谷本川流路の中心の平面形状

（図8 と同じ区間）

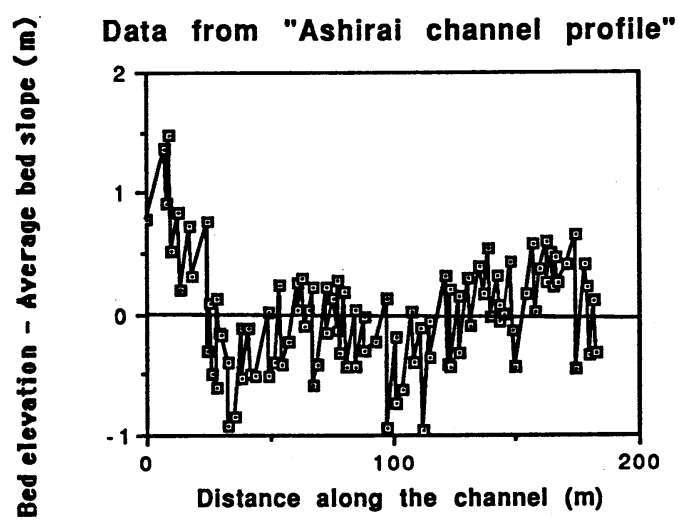

図8足洗谷本川における河床高から平均河床高 を差し引いた值の流路に沿ら分布

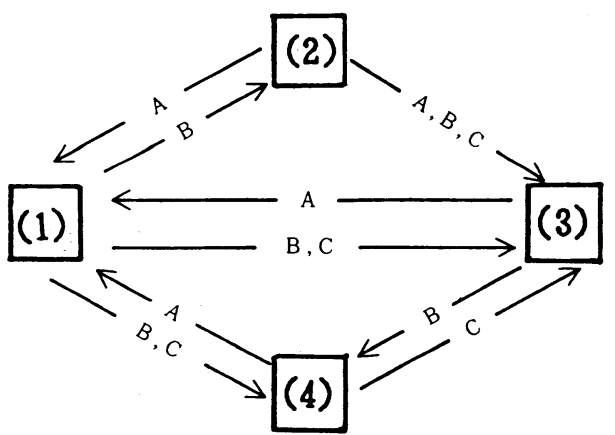

図10流路および流砂形態の変動過程

\section{$A$ : 流量減}

$B:$ 流量增加

$C:$ 流向変化

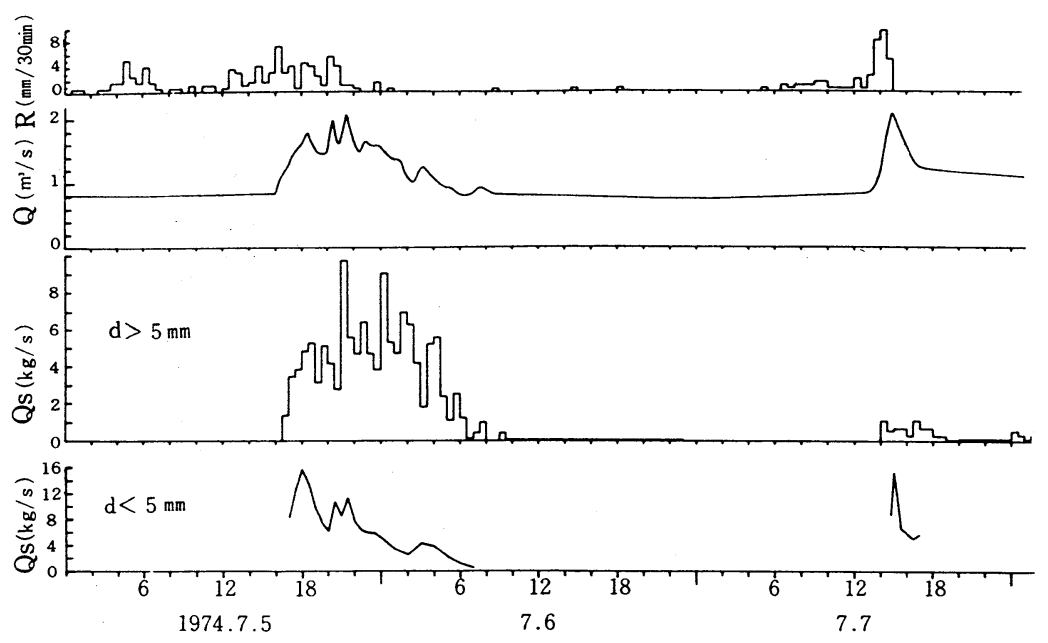

図11足洗谷本川の深谷観测点における土砂流出 （観測された砂磁は直径 $10 \mathrm{~cm}$ 以下） 
流量と流砂量の関係にこの柡な点を考虑しなければ ならない例として、A地点における流砂の観測結果を 図11に示す。この図において明らかなように、最大流 量が同程度の出水において、士砂流出量およびその時 間分布が異なる。この図において、三つの洪水の流砂 を比較すると、両者とも流量の增加に良く対応して流 砂が発生している。この栐に流量に対して時間遅れも なく流砂が発生しているのは、観測地点付近において 砂磷の移動が開始されたことを示している。流出砂硶 を粒径 $5 \mathrm{~mm}$ で二つに分けると、粒径が小さい方は最初 の流量ピークに対応して最大流砂量が発生しているの 対して、粒径の大きい方は遅れて最大流砂量が発生し ており、この様な移動形態の相違が階段状流路形態に 支配され、かつ、アーマーコートの破壊から形成過程 に重要な役割を演じているすのと考える。

さらに、この前後の洪水の流砂量を比較すると前の 洪水の方が流砂量が多く、特に粒径の大きなすのでは その差が大きい。この様な相違はアーマーコートの破 壊や渓岸侵食の規模および発生場所の違いなどによる むのと考える。この様な傾向は、観測された多くの出 水において認められている。図12は流量と流砂量の関 係を洪水毎に比較したもので、上記のような理由によ って、これらの関係が洪水毎に異なるすのと考える。 また、アーマーコートの破壊、溪岸侵食などが流路全 体に発生する事は少なく、どの栐な箅团で発生するか を評価することす重要な課題である。

\section{5. 土石流による流路の形成}

土石流の通過によって流路形態は大きく変化する。 ここでは、土石流の発生域と通過・堆積域に分けて検 討する。図13は発生域の平均勾配 $20^{\circ}$ の河床と河床の 高低差の分布を流路に沿って示している。この図のF において、河床の微小な変動は少なく、流路長 $100 \mathrm{~m}$ ら200mの単位で変動が㸾められる。この区間における 河床の形成が土石流の影響を受けたものと渓岸斜面か らの土砂供給に支配されるむのに分けられる。図中の $\mathrm{F}$ は渓岸斜面からの土砂供給の影響を受けている。図 中の $\mathrm{E}$ は土石流の発生による河床の侵食深の流路に沿 う分布を示しており、これは土石流の影響を受けてい る。侵食深の分布の特徵は上流部より下流部の方が僅 かに侵食梁が多くなっている。

土石流の痕跡幅の流路に沿う分布は図中のBに示す ように部分的に広くなっているが下流方向へ僅かに広

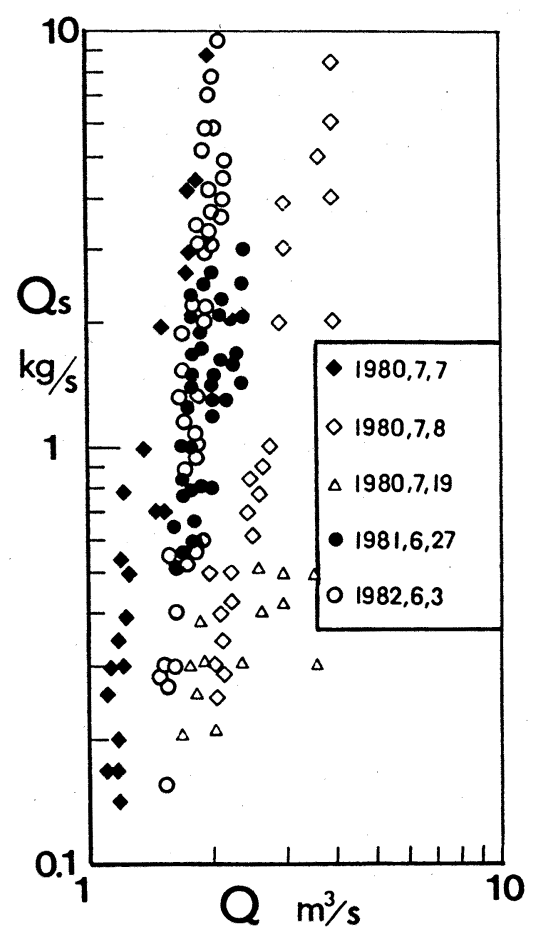

図12足洗谷本川における流量Qと流砂量Qsの関係

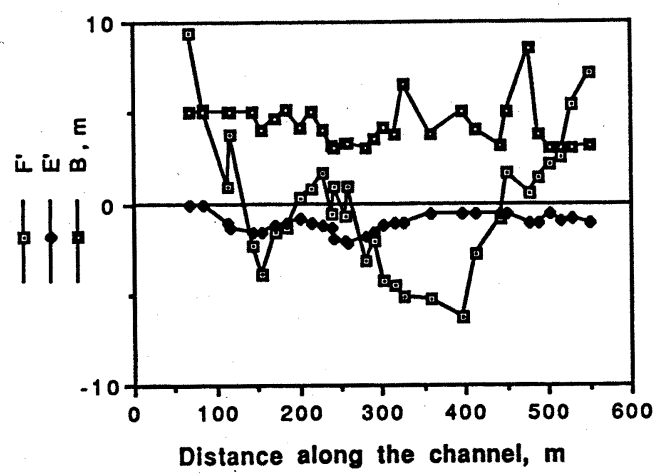

図13白水谷の中谷の河床

$\mathrm{F}$ : 河床高から平均河床高を引いた值

$\mathrm{E}$ : 河床侵食梁

$\mathrm{B}$ ：河床侵食幅 
くなる傾向が認められる。この様な下流方向への変化 が最大流量の変化に支配されているのか、流れが横断 方向に振れたことによるすのか検討の余地がある。

ついで、土石流の流動・堆積域の流路幅の分布と変 動状態を足洗谷本川のA地点の上流区間において検討 する。四14は最大痕跡幅の流路に沿う分布を示す。土 石流は図中のC 5 (最大流量 $320 \mathrm{~m}^{3} /$ 秒) およびC 8 ( 最大流量 $40 \mathrm{~m}^{3} /$ 秒) に示すように谷幅全体に拡がって いる。この様に土石流の規模に対して谷幅が狭い場合 は谷幅によって制限される。図中のC 1 からC 12まで の最大流量が $10 \mathrm{~m}^{3} /$ 秒以下の洪水では痕跡幅は $5 \mathrm{~m}$ から $15 \mathrm{~m}$ の間に分布し、かつ、流路幅 $10 \mathrm{~m}$ を中心に約 $200 \mathrm{~m}$ の波長を有する変動を示している。この様に流路幅の 流下方向の変化が、この区間の下流に砂防ダムを境に 接続する図9の流路における蛇行波長と同じ波長を有 することは興味梁い点である。

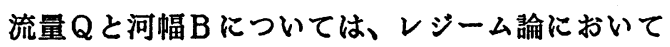
$\mathrm{B}=\mathrm{a} \mathrm{Q}^{1 / 2}$ のような経験的な関係が成り立つとされ ている。そこで、流量と河幅（最大痕跡）との関係を 図15において検討する。最大流量 $320 \mathrm{~m}^{3} /$ 秒を除けば、 係数 aの值が 3 から 6 の間で、その関係が成り立って いる。さらに、河幅 $\mathrm{B}$ 蛇行波長 Lの間に、 $\mathrm{L}=10 \mathrm{~B}$ の関係む認められる。しかし、谷幅に拘束されない範 四において河幅は流量に応じて变化するが、この流路 に沿った河幅の分布にかなりの規則性が認められ、ま た、蛇行との関連性す認められる。その他、この区間 において土石流の発生があっても新旧の流路の特徵に は変化が少ない。その一例として、蛇行波長が経年的 に変化しないのに対して、その振幅には変動が琶められ、その変動機構などあ含めて注目すべき点が多い。

\section{6 ・結語}

以上、本文においては流路形態と流砂について観測・調查の成果を中心に、階段状の流路における土砂調 節、アーマーコートの破壊などによる流砂特性の変化、土石流による新しい流路の形成および新旧流路の類 似性などについて検討を行った。また、流砂現象を予測するためには流路形態とその特性およびその変動な ぞが非常に重要であることを明らかにした。さらに、今後の課題として、階段状河道のステップ・プールの 規模が何によって支配されているのか、階段状流路の形成・破壊機構およびこれらの現象が発生する場所の 推定、蛇行流路の振幅の変動機構などの解明が重要であることを指摘した。

\section{参考文献}

1 ) 芦田和男・高橋 保・沢田豊明：山地流域における土砂流出の観測研究、第23回水理講演会論文集、 1979, pp.61-69.

2 ）沢田豊明・声田和男・高橋 保 : 山地河道における掃流砂の流送過程、第25回水理講演会論文集、1981 pp. 507-514.

3 ）沢田豊明・声田和男・高橋 保 : 山地河道の変動と砂れきの流出に関する研究、第26回水理講演会論文 集、1982,pp. 105-110.

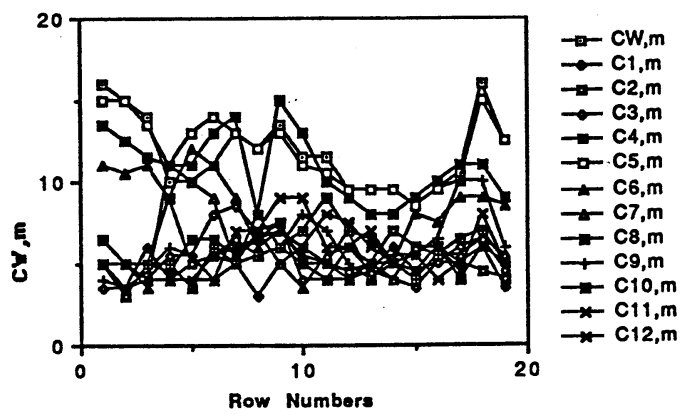

図14足洗谷本川における最大痕跡幅 の流路に沿う分布 (20m間隔)

$\mathrm{CW}_{\mathrm{max}}$ ：谷の幅

$\mathrm{C}_{\mathrm{m} \text { in }}$ : 平水時の水面幅

$\mathrm{C} 1 \cdots \mathrm{C} 12$ : 洪水・土石流後の痕跡

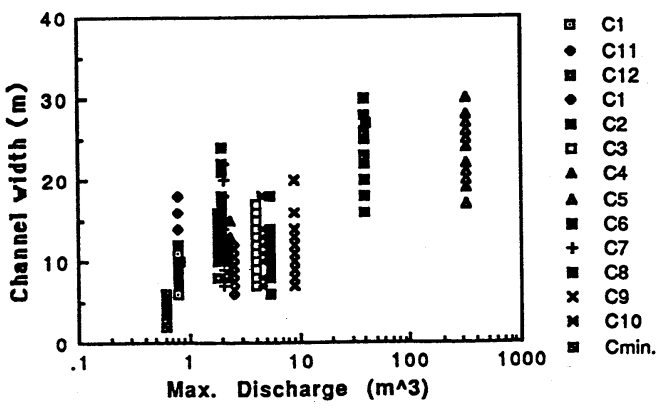

図15足洗谷本川における最大痕跡幅

と最大流量の関係（図14 と同じ区間） 